\title{
New or poorly-known millipedes (Diplopoda) from Papua New Guinea, 3
}

\author{
Новые и малоизвестные многоножкии-диплоподы \\ из Папуа - Новой Гвинеи. 3
}

\section{S.I. Golovatch ${ }^{1} \&$ Pavel Stoev $^{2}$ \\ С.И. Головач ${ }^{1}$, Павец Стоев ${ }^{2}$}

\footnotetext{
${ }^{1}$ Institute for Problems of Ecology and Evolution, Russian Academy of Sciences, Leninsky pr. 33, Moscow 117071 Russia.

${ }^{1}$ Институт проблем экологии и эволюции РАН, Ленинский проспект, 33, Москва 117071 Россия.

${ }^{2}$ National Museum of Natural History, Bulgarian Academy of Sciences, Blvd Tsar Osvoboditel 1, Sofia 1000 Bulgaria.

${ }^{2}$ Национален природонаучен музей БАН, бул. Цар Освободител 1, София 1000 България.
}

KEY WORDS: Diplopoda, taxonomy, Tectoporus, Eustrongylosoma, new species, Papua New Guinea. Гвинея.

КЛЮЧЕВЫЕ СЛОВА: Diplopoda, таксономия, Tectoporus, Eustrongylosoma, новый вид, Папуа - Новая

ABSTRACT. Five new Paradoxosomatidae are described from Papua New Guinea: Tectoporus bispinosus sp.n., T. wilhelmicus sp.n., T. spiniger sp.n., T. moniliformis sp.n. and Eustrongylosoma finimtel sp.n. A key is provided to all six species of Tectoporus currently known from New Guinea.

РЕЗЮМЕ. Из Папуа - Новой Гвинеи описаны пять новых видов семейства Paradoxosomatidae: Tectoporus bispinosus sp.n., T. wilhelmicus sp.n., T. spiniger sp.n., T. moniliformis sp.n. и Eustrongylosoma finimtel sp.n. Дан ключ для всех шести видов рода Tectoporus, ныне известных из Новой Гвинеи.

\section{Introduction}

This contribution continues our efforts in identifying the outstanding collection of millipedes taken in 1975 by Petar Beron, of the National Museum of Natural History Sofia (NMNHS), in Papua New Guinea [Golovatch \& Stoev, 2009; Golovatch et al., 2010]. It focuses on the large genus Tectoporus Carl, 1914, which is one of the dominant elements in the paradoxosomatid fauna of that country. In addition, another new Eustrongylosoma is described.

Most of the material treated hereafter has been housed in NMNHS, with only a few duplicates donated to the Zoological Museum, State University of Moscow, Moscow, Russia (ZMUM), as indicated below.

\section{Taxonomy}

Family Paradoxosomatidae

Tectoporus fugilil Golovatch \& Stoev, 2009 Figs $1 \& 2$.
MATERIAL. $1 \sigma^{7}$ (ZMUM), Papua New Guinea, Western Province, Bahrmann Mts, 2,260-2600 m a.s.l., south of Finim Tel Plateau, August 1975; $1 \mathrm{O}^{2}, 1$ क (NMNHS), Western Province, Finim Tel area, rain forest, 2,300 m a.s.l., August 1975, all leg. P. Beron \& Ph. Chapman.

REMARKS. This species has recently been described from Mt Fugilil, only a few air-km away from the above new localities. New illustrations of gonopod structure are given to confirm the species identity, as well as to show slight variation in the shape of the distal part of the solenophore (Figs $1 \& 2$ ).

\section{Tectoporus bispinosus sp.n.}

Figs 3-12.

HOLOTYPE O (NMNHS), Papua New Guinea: Western Province, Anawottuman (Camp I), 2,490 m a.s.l., fault controlled valley, October 1975, leg. H. Beck. - PARATYPES: $1 \sigma^{\top}, 1$ fragm. + (NMNHS), same locality, date and collector; $1 O^{\top}$ (ZMUM), Western Province, Bahrmann Mts, 2,260-2600 m a.s.l., south of Finim Tel Plateau, August 1975, leg. P. Beron \& Ph. Chapman.

DIAGNOSIS. Differs from congeners in the presence of two strong ventral spines at the base of the solenophore.

NAME. To emphasize the presence of two strong ventral spines at the base of the solenophore.

DESCRIPTION. Length ca 19 (holotype and $\sigma^{7}$ paratype from Bahrmann Mts) to $20 \mathrm{~mm}$ ( $\sigma^{7}$ paratype from Anawottuman and $O$ paratype), width of midbody pro- and metazona 1.7 and 2.0 (holotype), 1.5 and 1.8 ( $\sigma^{7}$ paratype from Bahrmann Mts) or 2.0 and 2.8 ( $\sigma^{7}$ paratype from Anawottuman), or 2.6 and $3.0 \mathrm{~mm}$ (+ paratype), respectively. Coloration dark brown with more or less contrastingly lighter yellow, grey-yellow or brown, mid-dorsal, rather broad spots on metaterga and prozona, always constricted near stricture between pro- and metazona, either in touch with each other (Anawottuman) or separated (Bahrmann Mts). 


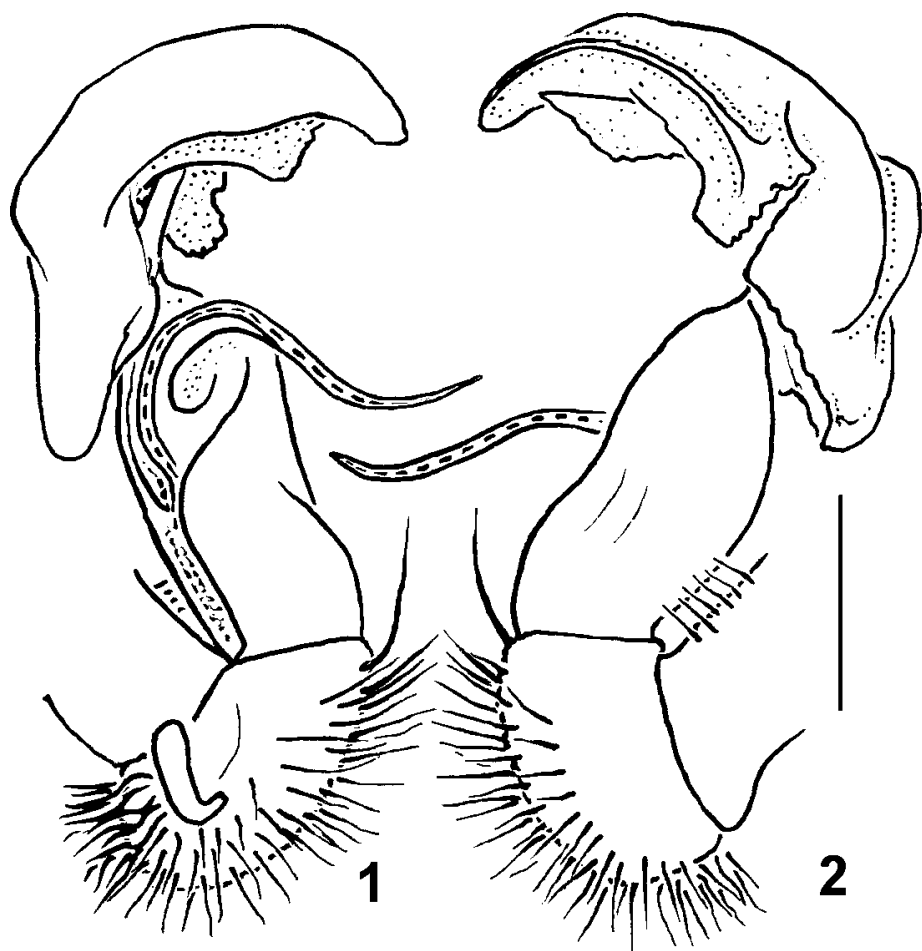

Figs 1 \& 2. Tectoporus fugilil Golovatch \& Stoev, 2009, $0^{7}$ from Bahrmann Mts, left gonopod, mesal and lateral views, respectively. Scale bar $0.2 \mathrm{~mm}$.

Рис. 1 и 2. Tectoporus fugilil Golovatch \& Stoev, 2009, О7 из гор Барманн, левый гонопод, соответственно изнутри и сбоку. Масштаб: 0,2 мм.
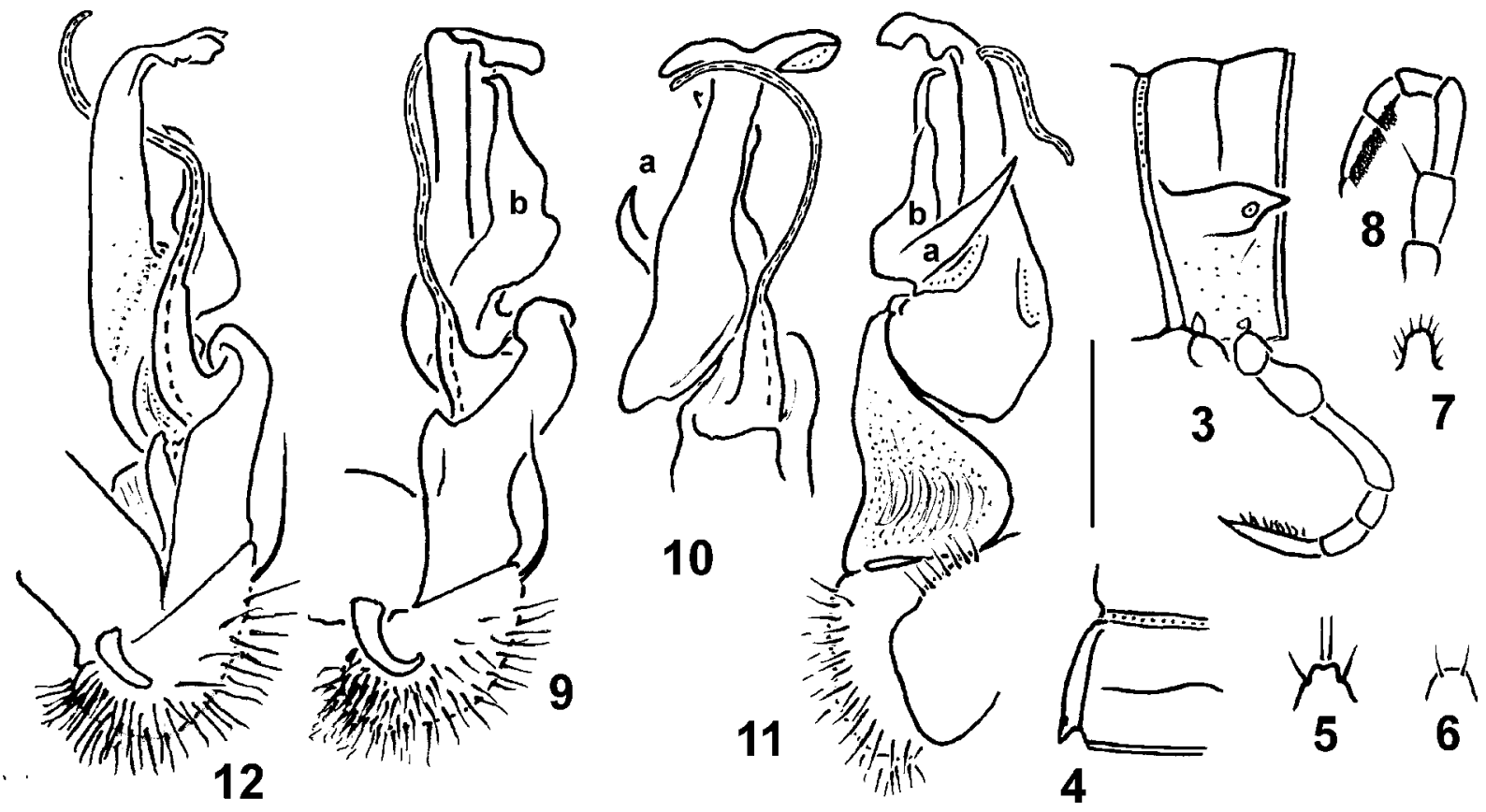

Figs 3-12. Tectoporus bispinosus sp.n., O paratypes from Bahrmann Mts (3-11) and Anawottuman (12): 3 - segment 10, lateral view; 4 - left half of metatergum 10, dorsal view; 5 - epiproct, dorsal view; 6 - hypoproct, ventral view; 7 - sternal lamina between coxae 4, ventrocaudal view; 8 - leg 3;9-12 - left gonopods, mesal, dorsal, lateral and mesal views, respectively. Scale bar: $1.0(3-8)$ and $0.2 \mathrm{~mm}(9-12)$.

Рис. 3-12. Tectoporus bispinosus sp.n., паратипы О7 из гор Барманн (3-11) и Анавоттумана (12): 3 - сегмент 10, вид сбоку; 4 - левая половина метатергита 10 , вид сверху; 5 - эпипрокт, вид сверху; 6 - гипопрокт, вид снизу; 7 - стернальная пластина между тазиками 4, вид снизу и сзади; 8 - нога 3; 9-12 - левые гоноподы, соответственно изнутри, сверху, сбоку и изнутри. Масштаб: 1,0 (3-8) и 0,2 мм (9-12). 
Antennae rather long, slender, reaching behind beyond segment 3 dorsally; head densely setose in clypeolabral region, vertex bare, epicranial suture distinct. In width, head $>$ collum $>5-17>2-4$; thereafter body gradually tapering. Paraterga in $\sigma^{r}$ low (Figs 3 \& 4), set at about $1 / 2$ midbody height, small, slightly enlarged on pore-bearing segments, well bordered dorsally, less strongly so ventrally in posterior $1 / 3$; caudal corner up to slightly surpassing rear tergal contour, more clearly so on segments 18 and 19; paraterga in 0 smaller and mainly only reaching rear tergal contour. Tegument smooth and shining, transverse metatergal sulcus present either on segments 5-18 or starting and barely visible only from segment 7 , always poorly expressed, line-shaped and superficial on segments 8-17, not reaching bases of paraterga; tergal setae missing, probably broken off, insertion points either invisible or very poorly traceable as $2+2$ on anterior half of metaterga, stricture very slightly ribbed dorsally and dorsolaterally. Ozopores lateral, located near caudal corner of paraterga (Figs $3 \& 4$ ), poreless paraterga considerably thinner at margin. Epiproct conical, subtruncate, preapical papillae very small (Fig. 5). Hypoproct semicircular, caudal setae strongly separated (Fig. 6). Axial line missing. Pleurosternal carinae in $\sigma^{7}$ present like arcuated ridges on segments 2-4, like caudal teeth gradually coming to naught towards segment 7 or 8 ; in \% less strongly developed, caudal teeth nearly wanting already on segment 5 . Surface below paraterga on places very delicately macrogranulate.

Sterna without modifications, cross-impressions modest; sternal lamina between $\sigma^{7}$ coxae 4 high, linguiform, setose (Fig. 7). Legs in $\sigma^{7}$ long and slender (Fig. 3), ca 2 times as long as midbody height; tarsal brushes evident until segment 8 , tibial brushes until leg 3 (Fig. 5), most of prefemora evidently bulged laterad; legs in $O$ slightly shorter and slenderer, ca 1.3 times longer than midbody height.

Gonopods (Figs 9-12) complex, coxites modestly setose ventrolaterally. Solenophore bifid, with two spiniform ventral processes (a and $\mathbf{b}$ ) at base.

REMARKS. Both of the above localities lie only a few air-km from each other.

\section{Tectoporus wilhelmicus sp.n.}

Figs 13-20.

HOLOTYPE $0^{7}$ (NMNHS), Papua New Guinea: Western Province, Wilhelm Mt, near Lake Aunde, 3,610 m a.s.1., 26.X.1975, leg. P. Beron.

DIAGNOSIS. Differs from congeners in the smooth stricture between pro- and metazona, coupled with the peculiar, complex shape of a biramous solenophore (see also key below).

NAME. To emphasize the type locality.

DESCRIPTION. Holotype incomplete, lacking head and segments $1-6$. Width of midbody pro- and metazona 1.7 and $2.0 \mathrm{~mm}$, respectively. Coloration dark, metaterga slightly infuscate. Paraterga set low (Figs 13 \& 14), mostly lying at about $1 / 2$ midbody height, small, only slightly enlarged on pore-bearing segments, distinctly bordered dorsally, less clearly so ventrally to about caudal 1/3-1/2 extent; caudal corner mostly subspiniform and slightly surpassing rear tergal contour (Figs $13 \& 14$ ), more clearly so on segments 18 and 19 . Tegument smooth and shining, transverse metatergal sulcus evident, superficial, line-shaped, reaching bases of paraterga; tergal setae missing, probably broken-off, insertion points $2+2$ in anterior half of metaterga; stricture smooth. Ozopores located near caudal corner of paraterga, poreless paraterga considerably thinner at margin. Epiproct broadly rounded, preapical papillae small but evident (Fig. 15). Hypoproct trapeziform, caudal setae strongly separated (Fig. 16). Axial line missing. Pleurosternal carinae missing at least from segment 7 on. Surface below paraterga smooth.

Sterna without modifications, cross-impressions modest. Legs long and slender, ca 2 times as long as midbody height; tarsal brushes present until segment 11, most of prefemora evidently bulged laterad (Fig. 17).

Gonopods (Figs 18-20) complex, telopodites evidently twisted. Solenophore biramous, each branch with several lobules and denticles.

\section{Tectoporus spiniger sp.n.}

Figs 21-27.

HOLOTYPE O (NMNHS), Papua New Guinea: Western Province, Finim Tel Plateau, 2,300 m a.s.l., rain forest, August 1975, leg. P. Beron \& Ph. Chapman. - PARATYPE: $\sigma^{7}$ (NMNHS), Finim Tel Plateau, Selminum doline, 2,300 m a.s.l., litter, 2.X.1975, leg. P. Beron \& Ph. Chapman.

DIAGNOSIS. Differs from congeners by the spiniform paraterga, coupled with the peculiar, rather complex shape of a uniramous solenophore.

NAME. To emphasize the spiniform paraterga, a noun in apposition.

DESCRIPTION. Length $17 \mathrm{~mm}$ (holotype). Paratype $\sigma^{\top}$ incomplete, head and segments 1-6 missing. Width of midbody pro- and metazona 1.6 and 3.0 ( $\sigma^{7}$ paratype) or 1.6 and $2.5 \mathrm{~mm}\left(\sigma^{7}\right.$ holotype) between tips of paraterga, respectively. Coloration uniformly yellowish $\left(\sigma^{7}\right)$. Antennae and legs evidently increasingly infuscate brown distad.

Antennae extremely long and slender, reaching behind beyond segment 5 dorsally. Head densely setose in clypeolabral region, nearly bare on vertex. Body very strongly moniliform. In width, segments 6-16(17) $>5>$ head $>2-4>$ collum. Paraterga present already on collum like small, rounded, caudolateral flaps; paraterga 2 and 3 as usual small ridges; paraterga 4 subspiniform, set high, at about 1/4 segment's height, but not reaching level of dorsum; subsequent paraterga (Figs 21 \& 22) very high, directed dorsocaudally, well surpassing both level of dorsum and rear tergal contour, spiniform, simple and pointed. Pore-bearing paraterga with a small front incision basally of ozopore. Tegument smooth and shining, transverse metatergal sulcus superficial, line-shaped, far from reaching bases of paraterga; tergal setae missing, probably broken-off, insertion points invisible; stricture faintly ribbed 

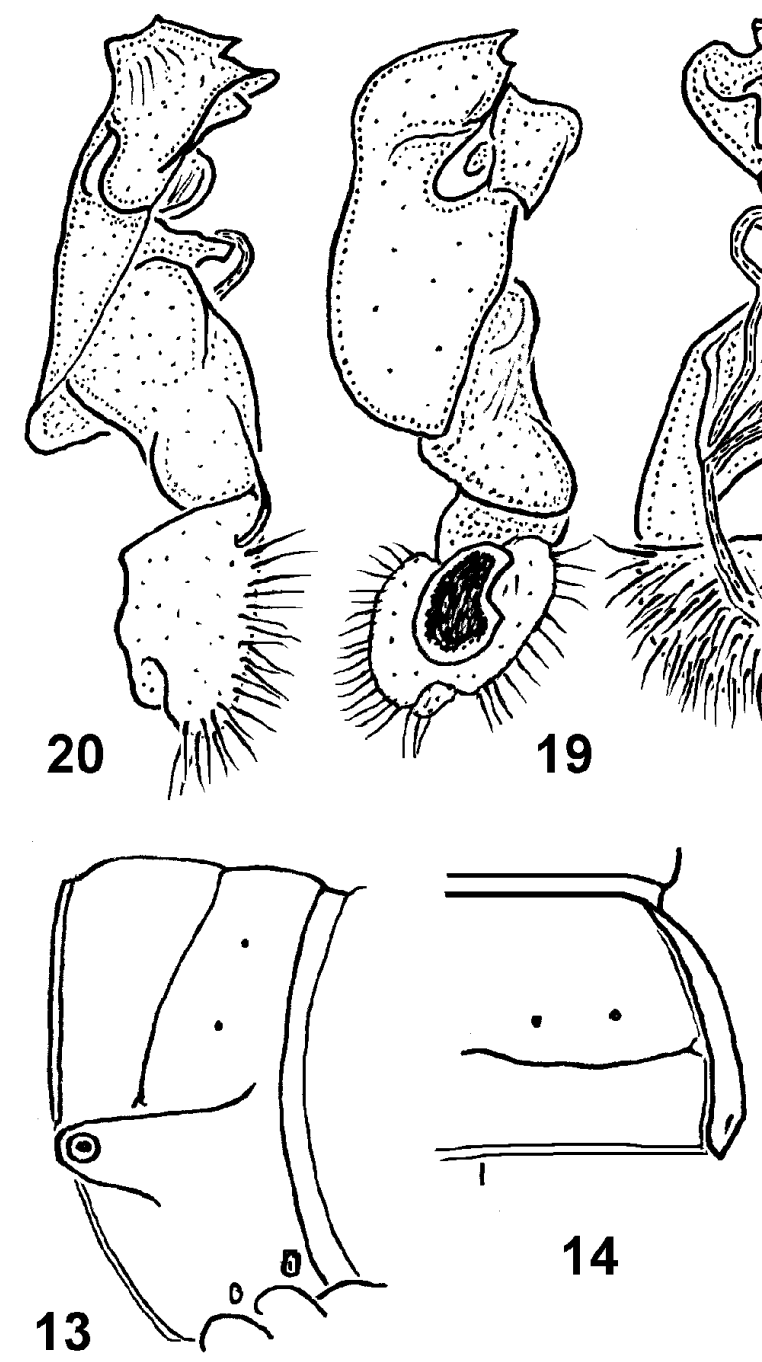

18
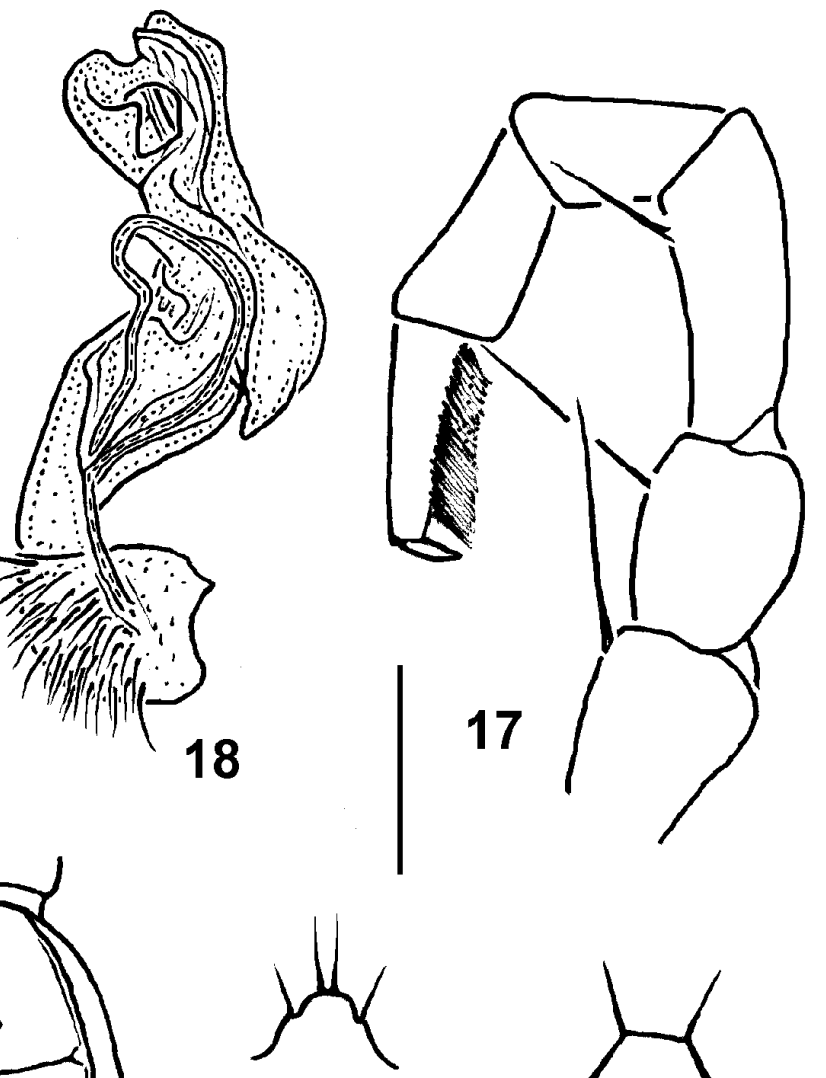

15

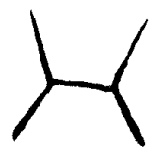

16

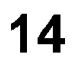

Figs 13-20. Tectoporus wilhelmicus sp.n., $\sigma^{\top}$ holotype: 13 - segment 10, lateral view; 14 - right half of metatergum 10, dorsal view; 15 - epiproct, dorsal view; 16 - hypoproct, ventral view; 17 - midbody leg; 18-20 - right gonopod, mesal, dorsal and lateral views, respectively. Scale bar: $0.5(13-16)$ and $0.2 \mathrm{~mm}(17-20)$.

Рис. 13-20. Tectoporus wilhelmicus sp.n., голотип О: 13 - сегмент 10, вид сбоку; 14 - правая половина метатергита 10, вид сверху; 15 - эпипрокт, вид сверху; 16 - гипопрокт, вид снизу; 17 - среднетуловищная нога; 18-20- правый гонопод, соответственно изнутри, сверху и сбоку. Масштаб: 0,5 (13-16) и 0,2 мм (17-20).

dorsally and dorsolaterally. Ozopores lying laterally at about $1 / 3$ off base of paraterga on an evident incision (Figs 21 \& 22); poreless and pore-bearing paraterga subequal. Pleurosternal carinae missing. Surface below paraterga smooth and shining. Epiproct subtruncate, preapical papillae very small (Fig. 23). Hypoproct semicircular, caudal setae strongly separated (Fig. 24). Axial line missing.

Sterna without modifications, cross-impressions very modest. Legs long and slender, ca 1.3-1.4 times longer than midbody height together with paraterga (Fig. 21); sternal lamina between $\sigma^{7}$ coxae 4 strongly curved anteriorly, linguiform, densely setose, reaching previous sternite; tarsal brushes present until segment 8; pregonopodal prefemora very slightly bulged laterally.
Gonopods (Figs 25-27) rather complex, telopodites evidently twisted. Solenophore devoid of evident teeth, but supplied with several lobes and lobules.

REMARKS. Due to the prominent, simple and spiniform paraterga, the appearance of $T$. spiniger sp.n. so strikingly resembles that of the so-called "dragon millipedes", genus Desmoxytes Chamberlin, 1923 (Orthomorphini), that it becomes increasingly clear that this remarkable character must have appeared in various paradoxosomatid lineages independently. Within the tribe Orthomorphini, such long and spiniform paraterga are observed only in a couple of Desmoxytes species: D. longispina (Loksa, 1960) and D. scutigeroides Golovatch, Geoffroy et Mauriès, 2010, both troglobites from southern China [Golovatch et al., 2010]. 

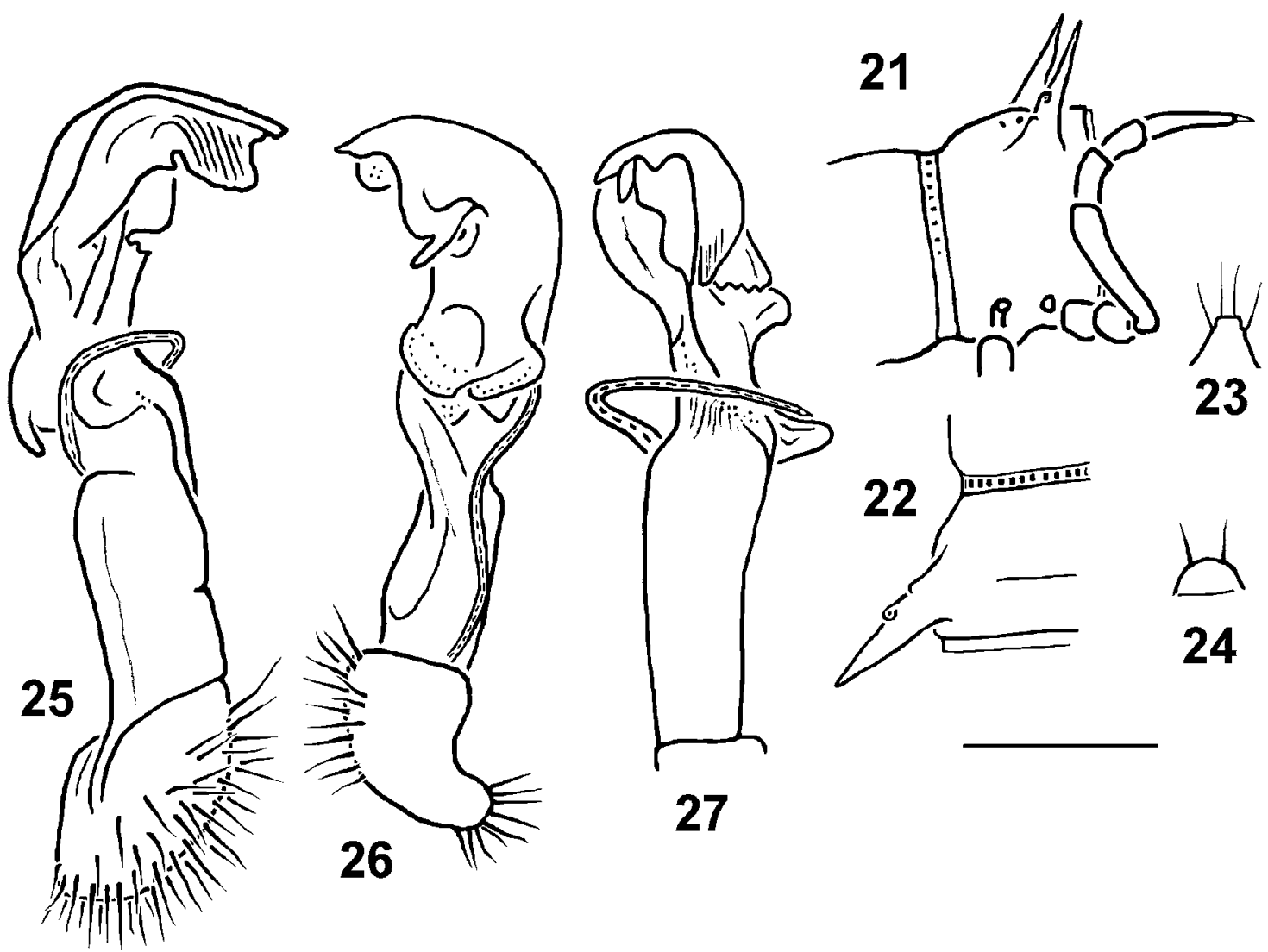

23

Figs 21-27. Tectoporus spiniger sp.n., $0^{7}$ paratype from Selminum doline: 21 - segment 10, lateral view; 22 - left half of metatergum 10, dorsal view; 23 - epiproct, dorsal view; 24 - hypoproct, ventral view; 25-27 - left gonopod, mesal, sublateral and ventral views, respectively. Scale bar: $1.0(21-24)$ and $0.2 \mathrm{~mm}(25-27)$.

Рис. 21-27. Tectoporus spiniger sp.n., паратип Оㄱ из лощины Селминум: 21 - сегмент 10, вид сбоку; 22 - левая половина метатергита 10 , вид сверху; 23 - эпипрокт, вид сверху; 24 - гипопрокт, вид снизу; $25-27$ - левый гонопод, соответственно изнутри, почти сбоку и снизу. Масштаб: 1,0 (21-24) и 0,2 мм (25-27).

Within the tribe Antichiropodini, the species Borneochiropus spinitergus Golovatch, 1996, from Borneo, has similarly long and spiniform paraterga [Golovatch, 1996]. Furthermore, a still unpublished species of "dragon-like" Antichiropodini with spine-shaped paraterga has recently been found in the Philippines as well [Nguyen Duc \& Sierwald, in litt.]. It is also noteworthy that the Australian Desmoxytoides hasenpuschorum Mesibov, 2004, another presumed antichiropodine, albeit untypical in being devoid of adenostyles [Mesibov, 2004], shows antler-shaped paraterga very similar to those observed in numerous Desmoxytes species. Now that we face a superficially "dragon-like" Tectoporus (Tectoporini), we are forced to admit parallel developments of antler- or spine-shaped paraterga at least in two or three different lineages of Paradoxosomatidae, while the vernacular term "dragon millipedes" must either be restricted to Desmoxytes or accepted to encompass a hopelessly heterogeneous assemblage of paradoxosomatid millipedes. Its only "character" then is the presence of either antler-shaped or spiniform paraterga. We prefer the former option as being justified historically, phylogenetically, as well as zoogeographically, because it is Desmoxytes that contains the first named "dragon" diplopod species, being also a fairly well delimited and basically continental Southeast Asian genus [Golovatch et al., 2010].

\section{Tectoporus moniliformis sp.n.}

Figs 28-34.

HOLOTYPE $0^{7}$ (NMNHS), Papua New Guinea: Western Province, Bahrmann Mts, 2,260-2600 m a.s.1., south of Finim Tel Plateau, August 1975, leg. P. Beron \& Ph. Chapman.

DIAGNOSIS. Differs from congeners in the strongly moniliform body, coupled with the distally enlarged sternal lamina between $\sigma^{7}$ coxae 4 , as well as the relatively simple solenophore supplied with a few laminar lobes (see also key below).

NAME. To emphasize the strongly moniliform body.

DESCRIPTION. Length $19 \mathrm{~mm}$, width of midbody pro- and metazona 1.1 and $1.5 \mathrm{~mm}$, respectively. Coloration uniformly castaneous brown, legs yellow except for infuscate (brown) tibiae and tarsi.

Head densely setose in clypeolabral region, nearly bare on vertex. Antennae long and slender, reaching behind middle of segment 5 dorsally. Body very strongly moniliform. In width, head $>6-15>$ collum $=5>2-4$; thereafter body gently tapering towards telson. Parater- 

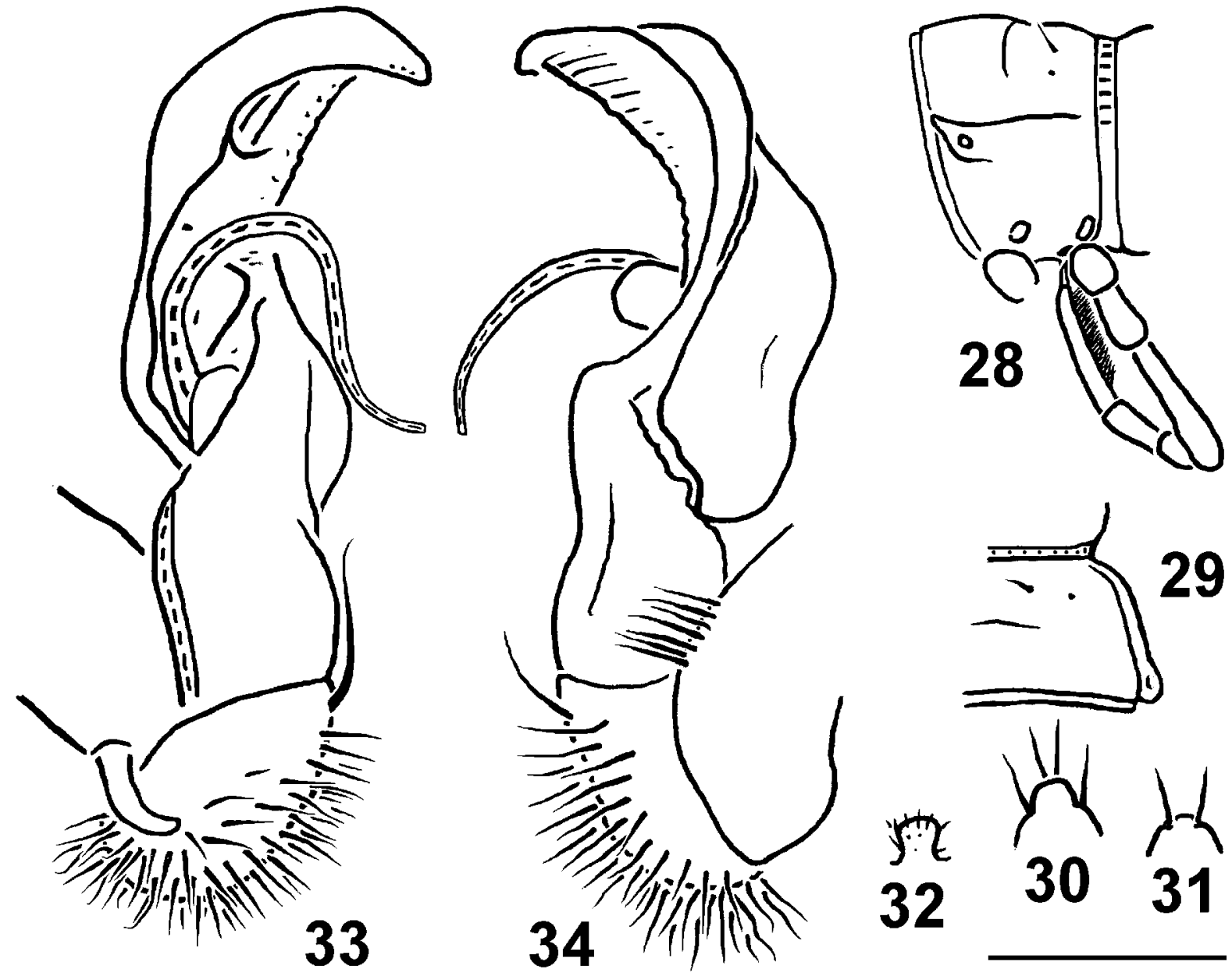

Figs 28-34. Tectoporus moniliformis sp.n., $0^{7}$ holotype: 28 - segment 10, lateral view; 29 - right half of metatergum 10, dorsal view; 30 - epiproct, dorsal view; 31 - hypoproct, ventral view; 32 - sternal lamina between coxae 4, ventrocaudal view; 33 \& 34 left gonopod, mesal and lateral views, respectively. Scale bar: $1.0(28-32)$ and $0.2 \mathrm{~mm}(33 \& 34)$.

Рис. 28-34. Tectoporus moniliformis sp.n., голотип О': 28 - сегмент 10, вид сбоку; 29 - правая половина метатергита 10, вид сверху; 30 - эпипрокт, вид сверху; 31 - гипопрокт, вид снизу; 32 - стернальная пластина между тазиками $4 ; 33$ и 34 - левый гонопод, соответственно изнутри и сбоку. Масштаб: 1,0 (28-32) и 0,2 мм (33 и 34).

ga very poorly developed (Figs $28 \& 29$ ), mainly like very small ridges or budges bordered dorsally and subcaudally ventrally; caudal corners always rounded and lying within rear tergal contour. Tegument smooth and shining, transverse metatergal sulcus very faint, like a short transverse impression on segments 6-16, far from reaching bases of paraterga; tergal setae $2+2$ in anterior half of segment, stricture faintly ribbed dorsally and dorsolaterally. Ozopores lying laterally near caudal corner of paraterga (Figs 28 \& 29); poreless paraterga slightly thinner. Pleurosternal carinae like poor ridges only on segments 2 and 3. Surface below paraterga smooth and shining. Epiproct rounded, preapical papillae small (Fig. 30). Hypoproct semi-circular, caudal setae strongly separated (Fig. 31). Axial line missing.

Sterna without modifications, cross-impressions modest. Legs long and slender, ca 2.0 times longer than midbody height; sternal lamina between $\sigma^{7}$ coxae 4 linguiform, densely setose, slightly broadened distad (Fig. 32); tarsal brushes present until segment 13 (Fig. 28), similar brushes on most prefemora but prefemora not bulged.

Gonopods (Figs 33 \& 34) relatively simple. Solenophore with only a few laminar lobes.

REMARKS. Six species of Tectoporus Carl, 1902 are currently known from New Guinea, including two described recently from the same collection: T. fugilil Golovatch et Stoev, 2009 and T. jeekeli Golovatch et Stoev, 2009 [Golovatch \& Stoev, 2009]. The following key can serve for their separation.

1(2) Paraterga spiniform, mostly lying well above dorsum (Figs $21 \& 22$ ). Gonopods as in Figs 25-27

T. spiniger sp.n. 


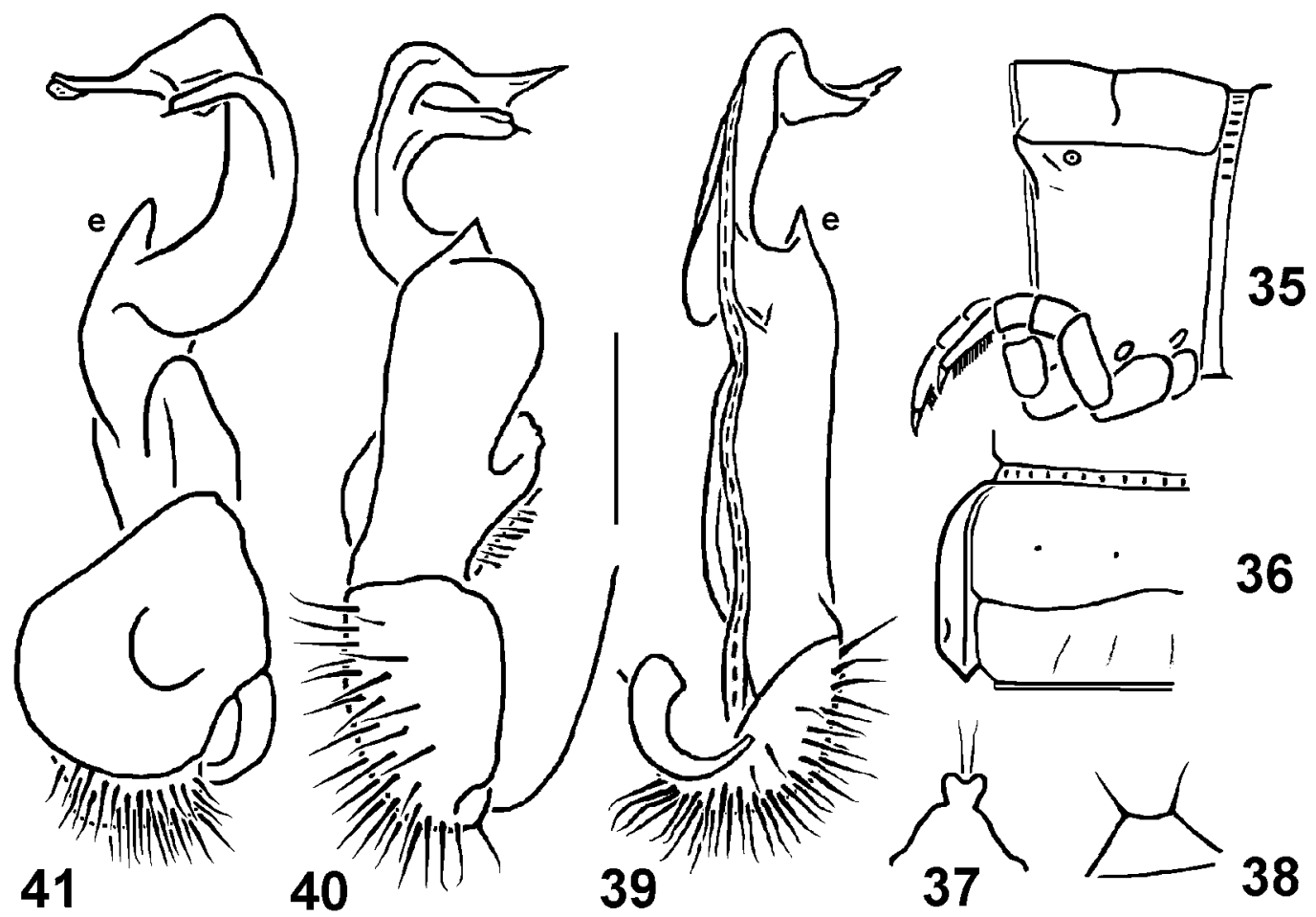

Figs 35-41. Eustrongylosoma finimtel sp.n., $0^{7}$ paratype: 35 - segment 10, lateral view; 36 - left half of metatergum 10, dorsal view; 37 - epiproct, dorsal view; 38 - hypoproct, ventral view; 39-41 - left gonopod, mesal, sublateral and subdorsal views, respectively. Scale bar: 0.5 (35-38) and $0.2 \mathrm{~mm}(39-41)$.

Рис. 35-41. Eustrongylosoma finimtel sp.n., паратип О?: 35 - сегмент 10, вид сбоку; 36 - левая половина метатергита 10, вид сверху; 37 - эпипрокт, вид сверху; 38 - гипопрокт, вид снизу; 39-41 - левый гонопод, соответственно изнутри, почти сбоку и почти сверху. Масштаб: 0,5 (35-38) и 0,2 мм (39-41).

2(1) Paraterga as usual, low ridges lying well below level of dorsum. Gonopods different.

3

3(4) Gonopod with two characteristic, ventral, spiniform processes at base of solenophore ( $\mathbf{a}$ and $\mathbf{b}$ in Figs 9-12) T. bispinosus sp.n.

4(3) Solenophore without evident spiniform processes ... 5

5(6) Transverse metatergal sulcus missing. Gonopod as in Figs $1 \& 2$, solenophore with two irregularly-shaped preapical lobes

T. fugilil

6(5) Transverse sulcus present on most metaterga. Gonopod different

7(8) Most of paraterga evidently rounded caudally in dorsal view (Fig. 29). Gonopod simpler, as in Figs 33 \& 34, preapical lobe of solenophore elongate and ribbed .......

T. wilhelmicus sp.n.

8(7) Most of paraterga (nearly) pointed caudally in dorsal view (Fig. 14). Gonopod more complex, preapical lobe of solenophore far less conspicuous

9(10) Solenophore biramous, especially complicated disally, basal fold of lamina lateralis simple (Figs 18-20) ...

T. moniliformis sp.n.

10(9) Solenophore uniramous, much simpler distally, basal fold of lamina lateralis ear-shaped T. jeekeli

Eustrongylosoma beroni Golovatch \& Stoev, 2009

MATERIAL: $2 \bigcirc^{7} \sigma^{7}, 1$ (NMNHS), Papua New Guinea: Western Province, Finim Tel area, rain forest, 2,300 m a.s.1., August 1975, leg. P. Beron \& Ph. Chapman.
REMARKS. This strikingly densely setose species has recently been described from Cave Ogon I, near the village of Goglme, Chimbu Province, Papua New Guinea [Golovatch \& Stoev, 2009]. That E. beroni is a troglophile at most is documented by the above epigean record as far away $(>300 \mathrm{~km})$ as Finim Tel Plateau in Western Province.

\section{Eustrongylosoma finimtel sp.n.}

Figs 35-41.

HOLOTYPE O (NMNHS), Papua New Guinea: Western Province, Finim Tel area, October 1975, leg. P. Beron. - PARATYPES: $1 \sigma^{7}, 1$ (NMNHS), same locality, date and collector, together with holotype.

DIAGNOSIS. Differs from and being disjunct among congeners in the clearly biramous solenophore, coupled with the presence of an evident ventroparabasal tooth (e) at its base.

NAME. To emphasize the type locality, a noun in apposition.

DESCRIPTION. Length ca $18 \mathrm{~mm}$ (holotype) or ca $16 \mathrm{~mm}$ ( $\sigma^{7}$ and 9 paratypes). Width of midbody proand metazona 1.1 and 1.5 (holotype), 1.0 and 1.4 ( $\sigma^{7}$ paratype) or 1.6 and $1.9 \mathrm{~mm}$ ( + paratype), respectively. Coloration uniformly light brown with a grey-yellow mid-dorsal region; sides of metaterga infuscate; venter 
and legs grey-yellow, antennae slightly infuscate distad; head and telson more flavous, yellowish.

Head densely setose in clypeolabral region, nearly bare on vertex. Antennae short and slightly clavate, barely reaching behind end of segment 2; antennomere 6 slightly longer than $2^{\text {nd }}(2.4: 2.2)$. In width, head $>$ segments $6-17>$ collum $=5>2-4$; thereafter body rapidly attenuating towards telson. Paraterga small (Figs 35 \& 36), set low, lying at about $1 / 3$ metazonital height, very slightly surpassing rear tergal contour on segments 7-19, caudal corner nearly pointed; paraterga distinctly bordered dorsally, far less evidently so ventrally even in caudal part; paraterga in $\circ$ even smaller. Tegument smooth and shining, transverse metatergal sulcus evident, line-shaped, reaching bases of paraterga; tergal setae $2+2$ in anterior part of metaterga, insertion points evident; posterior halves of metaterga very faintly rugulose on places. Ozopores lying near caudal corner of paraterga laterally (Figs $35 \& 36$ ), poreless and pore-bearing paraterga subequal. Pleurosternal carinae only as small flaps on segment 2. Surface below paraterga faintly microgranulate. Epiproct faintly concave at tip, preapical papillae very evident (Fig. 37). Hypoproct subtrapeziform, caudal margin very faintly concave, caudal setae on minute knobs, strongly separated (Fig. 38). Axial line missing.

Sterna with very small caudal cones near each posterior coxa, cross-impressions modest. Legs modestly long $\left(O^{7}\right)$ or short $(+)$, ca 1.2-1.3 $\left(O^{7}\right)$ (Fig. 35) to 1.0 1.1 ( $(+)$ times as long as metazonite height; in + especially slender. Sternal lamina between $\sigma^{7}$ coxae 4 directed anteroventrally, short and broad, linguiform, densely setose; tarsal brushes present until segment 12 (Fig. 35); prefemora normal.

Gonopods (Figs 39-41) rather simple, coxite modestly setose distoventrally. Telopodites rather long and slender; solenophore subfalcate, biramous in distal half, with both a lamina medialis and, especially, a lamina lateralis well-developed, with an evident ventropara- basal tooth (e); seminal groove running entirely on mesal side of femorite, solenomere long and flagelliform, sheathed nearly completely distally by proximal, shorter branch.

REMARKS. Thirteen species of Eustrongylosoma Silvestri, 1896 are currently known from New Guinea [Hoffman, 1978; Golovatch \& Stoev, 2009], including the recently described E. beroni Golovatch \& Stoev, 2009 , as well as E. finimtel sp.n. Using the key to New Guinea congeners provided by Hoffman [1978], the new species keys out as E. oenologum (Silvestri, 1895), because both show a similar colour pattern. However, they differ strikingly in gonopod structure (see diagnosis of E. finimtel sp.n.).

ACKNOWLEDGEMENTS. We are most grateful to the Bulgarian-Russian and Russian-Bulgarian interacademician exchange programmes which allowed us to work jointly on this collection in 2010 .

\section{References}

Golovatch S.I. 1996. The millipede family Paradoxosomatidae on Borneo, with contributions to the faunas of some other islands of the Sunda area (Diplopoda, Polydesmida) // Rev. Suisse Zool. T.103. Fasc.1. P.151-193.

Golovatch S.I., Stoev P. 2009. New or poorly-known millipedes (Diplopoda) from Papua New Guinea, $1 / /$ Arthropoda Selecta. Vol.18. Nos 3-4. P.125-130.

Golovatch S.I., Geoffroy J.-J., Mauriès J.-P. 2010. Two new species of the millipede genus Desmoxytes Chamberlin, 1923 (Diplopoda: Polydesmida: Paradoxosomatidae) from caves in southern China // Ibid. Vol.19. No.2. P.57-61.

Golovatch S.I., Stoev P., VandenSpiegel D. 2010. New or poorlyknown millipedes (Diplopoda) from Papua New Guinea, 2 // Ibid. Vol.19. No.3. P.129-143.

Hoffman R.L. 1978. Diplopoda from Papuan caves (Zoological Results of the British Speleological Expedition to Papua New Guinea, 1975, 4) // Int. J. Speleol. Vol.9 (for 1977). P.281-307.

Mesibov R. 2004. Dirt-encrusted and dragon millipedes (Diplopoda: Polydesmida: Paradoxosomatidae) from Queensland, Australia // Zootaxa. No.1354. P.31-44. 